\title{
ENTOMOLOGY
}

\section{Heteroptera collected in Valsesia, Northern Italy}

\author{
P. Dioli, ${ }^{1}$ C.M.T. Boggio, ${ }^{2}$ L. Limonta ${ }^{3}$ \\ ${ }^{1}$ Museo Civico di Storia Naturale, Milan; ${ }^{2}$ Amateur Entomologist, Galliate (NO); ${ }^{3}$ Department of Food, Environmental \\ and Nutritional Sciences, University of Milan, Italy
}

\begin{abstract}
The survey of Heteroptera carried out in 2016 along the nature path "Bosco dei Tigli" (Lime Trees Wood) in Piode (Piedmont, 900 $\mathrm{m}$ a.s.1.), highlighted 74 species, belonging to 68 genera in total. The number of species of each family well represents the Italian Heteroptera composition, with the prevalence of Miridae and Pentatomidae. The Miridae Criocoris nigripes var. apicalis (Fieber, 1861), a new record in the Alps, and Dicyphus flavoviridis (Tamanini, 1949), an Italian endemic taxon, were collected. Atractotomus parvulus (Reuter, 1878) and Orthotylus viridinervis (Kirschbaum, 1856) were recorded for the first time in Piedmont. Piode is the most Northern area, with Sondrio, where the Mediterranean Lygaeidae Oxycarenus lavaterae (Fabricius, 1784) was found.
\end{abstract}

\section{Introduction}

The historical and nature-oriented importance of natural trails and of the surrounding habitat has received more attention recent-

Correspondence: Lidia Limonta, Dipartimento di Scienze per gli Alimenti la Nutrizione, l'Ambiente, Università degli Studi di Milano, Via G. Celoria 2, 20133 Milano, Italia.

E-mail: lidia.limonta@unimi.it

Key words: Hemiptera, Orius (Heterorius) laticollis, Atractotomus parvulus, Criocoris nigripes var. apicalis, Dicyphus (Dicyphus) flavoviridis.

Contributions: the authors contributed equally.

Conflict of interest: the authors declare no potential conflict of interest.

Funding: none.

Received for publication: 11 December 2019.

Accepted for publication: 31 December 2019.

${ }^{\circ}$ Copyright: the Author(s), 2019

Licensee PAGEPress, Italy

Journal of Entomological and Acarological Research 2019; 51:8752

doi:10.4081/jear:2019.8752

This article is distributed under the terms of the Creative Commons Attribution Noncommercial License (by-nc 4.0) which permits any noncommercial use, distribution, and reproduction in any medium, provided the original author(s) and source are credited. ly, in order to enhance and protect the environment. Researches on biodiversity highlighted the great variety of animal and plant species that inhabit these areas (IPLA, 1989; Regione Piemonte, 2004, 2013).

Hemiptera Heteroptera presents a high number of species in Italy, more than 1500 , inhabiting all trophic niches. This taxon was the object of this research as it is a good indicator of the ecosystem's health. In fact, the Heteroptera species recorded in a biotope give information on the characteristics of the environment. Samples were collected in 2016 in Valsesia along the path "Il Bosco dei Tigli", recovered with funding from Piedmont Region and the European Community. The trail is in Piode Municipality (Vercelli Province), located $900 \mathrm{~m}$ a.s.l.

\section{Materials and Methods}

The species of Heteroptera were collected along the trail "Il Bosco dei Tigli” from May to November 2016.

The first sampling area (1), close to the village, was characterized by sessile oak (Quercus petraea (Matt) Liebl.), and linden (Tilia cordata Mill.). The contiguous area (2) was a meadow/pasture at $900 \mathrm{~m}$ a.s.1, with the prevalence of Phyteuma betonicifolium Vill., Ranunculus acris L., Gentiana kochiana E.P.Perrier \& Songeon, Fragaria vesca L., Salvia glutinosa L., and Primula vulgaris Huds. The third sampling area (3) was a deciduous forest composed by Populus tremula L., T. cordata, Q. petraea, Castanea sativa Mill., Betula pendula Roth, Corylus avellana L., Sorbus aucuparia L., and Laburnum alpinum (Mill.) Bercht \& J. Presl. The last sampling area (4) was close to a waterfall with Festuca scabriculmis (Hack.) K.Richt., typical of Valsesia, Phyteuma scheuchzeri All., Saxifraga cuneifolia L., Saponaria ocymoides L., Primula hirsuta All., Calluna vulgaris (L.) Hull, Cytisus scoparius L., and Crataegus monogyna Jacq.

Species were identified using the main dichotomous keys of Heteroptera (Wagner \&Weber, 1964; Péricart 1972, 1987, 1998; Moulet 1995) and verified by comparison with the specimen in the collection of the Museum of Natural Science in Milan (P. Dioli).

\section{Results}

The species collected in the four sampling areas along the trail are reported in Table 1. 
Table 1. Hemiptera Heteroptera collected in the four areas along the trail "Il Bosco dei Tigli". The roman numerals provide the month. Corotypes (COR) according to Vigna Taglianti et al. (1999).

\begin{tabular}{|c|c|c|c|c|c|}
\hline Taxa & 1 & 2 & 3 & 4 & COR \\
\hline \multicolumn{6}{|c|}{ Anthocoridae } \\
\hline Anthocoris nemoralis (Fabricius, 1794) & & & VII & & ASE \\
\hline Dufouriellus ater (Dufour, 1833) & & VII & & & EUM \\
\hline Orius (Heterorius) laticollis (Reuter, 1884) & & VII & VIII & & EUR \\
\hline Orius (Orius) niger (Wolff, 1811) & & VIII & & & TEM \\
\hline \multicolumn{6}{|c|}{ Nabidae } \\
\hline Himacerus (Aptus) mirmicoides (O. Costa, 1834) & VIII & V,VI,VII,VIII & VII,VIII, IX & IX & EUM \\
\hline Himacerus (Himacerus) apterus (Fabricius, 1798) & & & VII, VIII & & ASE \\
\hline Nabis (Nabis) rugosus (Linnaeus, 1758) & & VI, VII, VIII, IX & VIII & VI, VIII, IX & SIE \\
\hline \multicolumn{6}{|c|}{ Miridae } \\
\hline Adelphocoris lineolatus (Goeze, 1778) & & & VIII & & OLA \\
\hline Adelphocoris seticornis (Fabricius, 1775) & & VIII & & & SIE \\
\hline Atractotomus parvulus Reuter, 1878 & & VII & & & $\mathrm{CEU}$ \\
\hline Blepharidopterus angulatus (Fallen, 1807) & & & VII & & SIE \\
\hline Bryocoris pteridis (Fallen, 1807) & & & VIII & & SIE \\
\hline Capsus ater (Linnaeus, 1758) & & VI & & - & EUM \\
\hline Charagochilus (Charagochilus) weberi Wagner, 1953 & & & VII & & EUR \\
\hline Closterotomus norwegicus (Gmelin, 1790) & & & VIII & & SEM \\
\hline Criocoris nigripes Fieber, 1861 (var. apicalis, Fieber, 1864) & & VI & & & $\mathrm{CEU}$ \\
\hline Deraeocoris (Deraeocoris) ruber (Linnaeus, 1758) & & VII, VIII & & & OLA \\
\hline Deraeocoris (Camptobrochis) serenus (Douglas \& Scott, 1868) & & VIII & VII, IX & & TEM \\
\hline Dicyphus (Dicyphus) flavoviridis Tamanini, 1949 & & V, VIII & $\mathrm{V}, \mathrm{IX}$ & & END \\
\hline Halticus apterus (Linnaeus, 1758) & & VII & & & TEM \\
\hline Harpocera thoracica (Fallen, 1807) & & & VI & & TEM \\
\hline Heterocordylus (Heterocordylus) tibialis (Hahn, 1833) & & & V & & EUR \\
\hline Lepidargyrus ancorifer (Fieber, 1858) & & $\mathrm{VI}$ & & & MED \\
\hline Liocoris tripustulatus (Fabricius, 1781) & T & VII & & & PAL \\
\hline Lygus gemellatus (Herrich-Schäffer, 1835) & & & & VI & MED \\
\hline Monalocoris (Monalocoris) filicis (Linnaeus, 1758) & & & & $\mathrm{VI}$ & SIE \\
\hline Neolygus contaminatus (Fallen, 1807) & & VII & & & SIE \\
\hline Orthotylus (Orthotylus) viridinervis (Kirschbaum, 1856) & & VII & & & EUR \\
\hline Phylus (Phylus) coryli (Linnaeus, 1758) & & & VIII & & EUR \\
\hline Phytocoris (Ktenocoris) austriacus Wagner, 1954 & & & VIII & VIII & $\mathrm{CEU}$ \\
\hline Pinalitus cervinus (Herrich-Schäffer, 1841) & & & VII & & CEM \\
\hline Plagiognathus (Plagiognathus) arbustorum (Fabricius, 1794) & & $\mathrm{VI}$ & & & PAL \\
\hline Plagiognathus (Plagiognathus) chrysanthemi (Wolff, 1804) & & & $\mathrm{VI}$ & & PAL \\
\hline Stenodema (Stenodema) holsata (Fabricius, 1787) & & V, VI, VII, IX & $\mathrm{VI}$ & & PAL \\
\hline Stenodema (Stenodema) laevigata (Linnaeus, 1758) & & V, VI, VII, VIII & V, VII, VIII & V & PAL \\
\hline Stenodema (Stenodema) sericans (Fieber, 1861) & & V & VIII, IX & VIII & EUR \\
\hline Stenodema (Stenodema) virens (Linnaeus, 1767) & & IV & & & OLA \\
\hline Stenotus binotatus (Fabricius, 1794) & & & VIII & & OLA \\
\hline \multicolumn{6}{|c|}{ Tingidae } \\
\hline Corythucha arcuata (Say, 1832) & VIII & V, VIII & V, VIII & $\mathrm{V}, \mathrm{VII}$ & OLA \\
\hline Dictyla echii (Schrank, 1782) & & & VIII & & PAL \\
\hline Physatocheila dumetorum (Herrich-Schäffer, 1838) & & & VII & & CEM \\
\hline \multicolumn{6}{|c|}{ Alydidae } \\
\hline Alydus calcaratus (Linnaeus, 1758) & & & VIII & & OLA \\
\hline \multicolumn{6}{|c|}{ Coreidae } \\
\hline Ceraleptus gracilicornis (Herrich-Schäffer, 1835) & & VI & & & TEM \\
\hline Coreus marginatus (Linnaeus, 1758) & & IX & & & ASE \\
\hline
\end{tabular}


The survey showed differences among the four areas sampled, underlining the ecological characteristics of the Heteroptera species collected.

The first area, the closest to the village, was characterized by species widespread in Italy, namely Himacerus (Aptus) mirmicoides (O. Costa, 1834), Aphanus rolandri (Linnaeus, 1758), and Pyrrhocoris apterus (Linnaeus, 1758). Also, the Nearctic Corythucha arcuata (Say, 1832), since its introduction in Europe, is common on oak in North Italy, while Tritomegas rotundipennis (Dohrn, 1862) is recorded locally in Italy, Spain, France, Germany, Austria, and Slovenia.

Meadows and pastures of area 2 presented the highest number of species (Figure 1). The abundance of plant species favored the presence of Pentatomidae and Scutelleridae, mainly collected in this part of the trail. Particularly noteworthy were Myrmus miriformis (Fallen, 1807), Lygaeosoma sardeum Spinola, 1837, and Macroplax preyssleri (Fieber, 1837), typical of dry meadows. A predator endemic species, Dicyphus (Dicyphus) flavoviridis Tamanini 1949 was collected on Salvia glutinosa L. in May and August.

In the undergrowth of the third sampling area, $A$. mirmicoides, Oxycarenus (Oxycarenus) lavaterae (Fabricius, 1787), and Palomena prasina (Linnaeus, 1761) were collected on Cytisus scoparius L. and Avenella flexuosa (L.) Drejer. Drymus (Sylvadrymus)

Table 1. Continued from previous page.




ryeii Douglas \& Scott, 1865 and Stenodema (Stenodema) laevigata (Linnaeus, 1758) were characteristic of the wet undergrowth. Elasmucha grisea (Linnaeus, 1758) in June and Kleidocerys resedae (Panzer, 1797) from May to August were recorded on birch and heather. Corythucha arcuata (Say, 1832) was the predominant species on the crown of the tree, together with Himacerus (Himacerus) apterus (Fabricius, 1798), an important predator of microarthropods.

Around the waterfall in the fourth sampling area two predators were collected, Nabis rugosus (Linnaeus, 1758), on Ericaceae, and Picromerus bidens (Linnaeus, 1758), which preys on moths' larvae.

Pyrrhocoris apterus (Linnaeus, 1758) was recorded in foliar debris in all the sampling area.

Family Miridae was the most represented, including $42 \%$ of the species collected, which was 31 species out of 74 Heteroptera species. Pentatomidae and Lygeidae species constituted 15\% and $12 \%$ respectively. Considering the diet of the species, $77 \%$ were phytophagous, $13 \%$ predatory, $7 \%$ omnivorous, and $3 \%$ granivorous.

The following species are worth mentioning for their significance in the considered area.

Orius laticollis (Reuter, 1884). Species recorded in Italy in the Northern and Southern Regions and in Sicily, in the wet areas and the edge of streams, where it predates mainly on Salix and, to a lesser extent on Alnus Mill., Populus L., Ulmus L., Quercus (L.) and Sorbus L. (Pericart 1972).

Atractotomus parvulus (Reuter, 1878). The first record in Piedmont, it was previously generically cited for the Northern regions of Italy (Kerzhner \& Josifov 1999). Monovoltine, it occurs on conifers (Pinus L., Abies Mill.), and overwinters as an egg (Wagner \& Weber 1964). This species is very close to Atractotomus marcoi (Carapezza, 1982) recorded in Sicily and Russia (Carapezza, 1982), recognizable by the smaller size, the shorter second antennal segment, and the structure of the male genitalia, especially the vesica. The female of $A$. parvulus from Valsesia has the second antennal segment longer than the width of the head, more strongly inflated and fusiform. Moreover, the basal part of exocorium is clear. The distribution of these two species must be better clarified on the basis of a series of specimens, as they may have been confused one with the other in the past (Stonedahl, 1990).



Figure 1. Number of species of Heteroptera collected in the four sampling areas along the natural path in Valsesia (NO).
Criocoris nigripes var. apicalis Fieber, 1864. The variety and the nominal form were recorded in Friuli, Trentino (Servadei 1967), and Piedmont (Dioli 1980). The specimen collected in Valsesia was the first in the Alpine area of Piedmont. In fact, previously, one adult was recorded in spring in Rovasenda (Novara) moorland, therefore two generations per year are assumed (Dioli, 1980). The species overwinters as an egg, and it colonizes Galium L. Adults are active in June-July (Wagner \& Weber, 1964). C. nigripes var. apicalis is a new combination, previously associated with C. crassicornis (Hahn, 1834).

Orthotylus viridinervis (Kirschbaum, 1856). Sporadically recorded in Northern and Southern Italy, this is the first report in Piedmont. The species overwinters as an egg, thrives on Fraxinus ornus L., seldom on other plants. Adults are active from July to August (Wagner \& Weber 1964).

Corythucha arcuata (Say, 1832). Nearctic species, recorded in the Alps and in the plain in Northern Italy, since 2000 (Bernardinelli and Zandigiacomo, 2000), later in Switzerland, Bulgaria, Turkey, and Iran. Spontaneous and planted oaks host this species (Dioli et al., 2007).

Drymus ryeii (Douglas \& Scott, 1865). Infrequent in Italy, recorded North of Po River in broadleaves residues and under stones (Dioli, 1974).

Oxycarenus lavaterae (Fabricius, 1787). Mediterranean species, the presence in the alpine and sub-alpine areas is considered occasional. Overwintering adults caused alarm several times as they aggregate on the bark of broadleaved plants (Capra 1961; Perini \& Tamanini, 1961; Tamanini 1961; Ciampolini \& Trematerra, 1986-1987).

\section{Conclusions}

In the survey, carried out along the nature path "Bosco dei Tigli" (Lime Tree Wood) at $900 \mathrm{~m}$ a.s.l. in Valsesia (Piedmont), 74 species of Heteroptera, belonging to 68 genera and 13 families, were collected in total. The number of species for each family represented the composition of the Italian Heteroptera, with the predominance of Miridae and Pentatomidae.

The chorology showed that $50 \%$ of the species collected are Euro-Asiatic sensu lato. Palearctic and European species constituted $25 \%$ and $17 \%$, respectively. Cosmopolitan species were insignificant, $1.1 \%$ and only one endemic species was recorded, Dicyphus (Dicyphus) flavoviridis.

The ubiquitous or pest species Dolycoris baccarum (L.), Stenodema (Stenodema) sericans (Fieber), S. (S.) virens (L.), S. (S.) laevigata (L.), and Coriomeris denticulatus (Scopoli) were mainly detected in the wide meadow areas, once cultivated, characterized by Poaceae, Fabaceae, and Asteraceae. The presence of phytophagous species was balanced with predator species.

The only allochthonous species Corythuca arcuata (Say), incidentally introduced in Italy in 2000 (Bernardinelli and Zandigiacomo, 2000), was collected in all the sampling areas.

In the area considered, of particular note were the first record in Piedmont of Atractotomus parvulus (Reuter), the second record in Piedmont and the first in the Alpine area of Criocoris nigripes (Fieber), the new in Piedmont and second record in northern Italy of Orthotylus viridinervis (Kirschbaum), and the record of Oxycarenus lavaterae (F.) as Piode is the most norther- 
ly locality in Italy, together with Sondrio, where the species was recently collected also at considerable height (M. Salvetti communication).

The species collected were mainly typical of the Alps, but Mediterranean species were also collected in the sunny area, in the meadows or on Cytisus scoparius L., while European and Siberian species were common in linden, hazelnut, oak, and chestnut sciophilous forest.

\section{References}

BERNARDINELLI I., ZANDIGIACOMO P., 2000 - Prima segnalazione di Corythucha arcuata (Say) (Heteroptera, Tingidae) in Europa. - Inf. Fitopat. 50: 47-49.

CAPRA F., 1961 - Note su ammassamenti di Oxycarenus lavaterae (F.) nel Polesine (Hemiptera, Heteroptera, Lygaeidae). - Studi Trentini Sci. Nat., XXXVIII: 182-187.

CARAPEZZA, A., 1982 - Il genere Atractotomus in Sicilia e in Calabria (Heteroptera, Miridae). - Naturalista Siciliano 6: 41-48.

CIAMPOLINI M., TREMATERRA P., 1986/1987 - Biological studies on Oxycarenus lavaterae (F.) (Rhynchota Heteroptera Lygaeidae). - Boll. Zool. Agr. Bachic. II 19: 187-197.

DIOLI P., 1974 - Emitteri Eterotteri nuovi o poco noti della Valtellina (Hemiptera, Heteroptera). - Mem. Soc. Entom. Ital., Genova 53: 30-38.

DIOLI P., 1980 - Eterotteri della Brughiera di Rovasenda (Piemonte). Quaderni sulla "Struttura delle zoocenosi terrestri”. 1. La Brughiera pedemontana. - Roma. Collana del Programma finalizzato "Promozione della qualità dell'ambiente" del C.N.R.: 35-56.

DIOLI P., GIACALONE FORINI I., MORETTI M., SALVETTI M., 2007 - Note sulla distribuzione di Corythucha arcuata (Insecta, Heteroptera, Tingidae) in Cantone Ticino (Svizzera), Valtellina e alto Lario (Lombardia, Italia). - Il Naturalista Valtellinese - Atti museo civ. Storia naturale Morbegno 18:59-68.

IPLA, 1985 - Piano Naturalistico del Parco Naturale Alta Valsesia - Regione Piemonte.
KERZNER I. M., JOSIFOV MOULET M., 1999 - Cimicomorpha II. Miridae. In: AUKEMA B. \& RIEGER, C. (Eds.) Catalogue of the Heteroptera of the Palaearctic Region Vol. 3. Netherlands Entomological Society, Amsterdam.

MOULET P., 1995 - Hemiptères Coreoidea (Coreidae, Rhopalidae, Alydidae), Pyrrhocoridae, Stenocephalidae euromediterranéens. - Faune de France 81: 336 pp.

PERICART J., 1972 - Hémipteres Anthocoridae, Cimicidae, Microphysidae de l'Ouest-Paléarctique. Faune de l'Europe et du Bassin Méditerrané Vol.7: IV + 402 pp. Masson et C.ie, Paris.

PERINI T., TAMANINI L., 1961 - Osservazioni sulla comparsa in massa di Oxycarenus lavaterae (F.) (Hemiptera, Heteroptera, Lygaeidae). - Studi Trentini Sc. Nat. XXXVIII: 57-66.

REGIONE PIEMONTE 2004 - Indagini e studi finalizzati alla predisposizione del piano di tutela delle acque. D. Lgs. 152/99.

REGIONE PIEMONTE (provincia di Vercelli, Parco Naturale alta Valsesia), 2013 - Carta degli habitat forestali di interesse comunitario nei SIC IT1120028 “Alta Valsesia” e IT1120006 "Val Mastallone".

SERVADEI, A., 1967 - Fauna d'Italia: Rhyncota, Heteroptera e Homoptera Auchenorrhyncha. Catalogo topografico. Bologna, Calderini, 1967.

STONEDAHL, G.M., 1990 - Revision and cladistic analysis of the Holarctic genus Atractotomus Fieber (Heteroptera: Miridae: Phylinae). - Bull. Am. Mus. Nat. Hist. 198: 1-88.

TAMANINI L., 1961 - Alcune osservazioni sulla biologia dell'Oxycarenus lavaterae (Fabr.) (Heteroptera, Lygaeidae). Mem. Soc. Ent. Ital. Genova, 40: 141-143.

VIGNA TAGLIANTI A., AUDISIO A. P., BIONDI M., BOLOGNA M.A., CARPANETO G.M., DE BIASE A., FATTORINI S., PIATTELLA E., SINDACO R., VENCHI A., ZAPPAROLI M., 1999 - A proposal for a chorotype classification of the Near East fauna, in the framework of the Western Palearctic region. Biogeographia J. Integr. Biogeogr. 20: 31-59.

WAGNER E., WEBER H.H., 1964 - Hétéroptères Miridae. - Faune de France 67: 1-592. 